\title{
De Greimas a Eric Landowski. A experiência do sentido, o sentido da experiência: semiótica, interação e processos sócio-comunicacionais
}

\author{
Paolo Demuru' \\ https://orcid.org/0000-0003-1559-9530 \\ I - Universidade Paulista \\ São Paulo (SP), Brasil
}

Resumo: Objetivo do presente artigo é reconstruir as trajetórias que unem o pensamento de Greimas e Landowski. Em particular, o confronto entre os dois autores desenvolve-se a partir de quatro diretrizes específicas: teórica, metodológica, epistemológica, política. Ao cerne da primeira coloca-se a questão do ponto de vista semiótico sobre os processos socioculturais e comunicacionais e a problemática greimasiana da narratividade, expandida e redefinida por Landowski em seu modelo dos regimes de sentido e interação; a segunda foca nos desafios do método semiótico diante da complexidade do mundo e da comunicação contemporânea; a terceira gira em torno do tema da emergência e da transformação do sentido; a quarta, por fim, tange às implicações políticas da abordagem semiótica. Trata-se de trajetórias elípticas, através das quais emerge um percurso não linear e errático, cujas intenções, longe de ser filológicas e sistêmicas, são, antes de tudo, críticas e especulativas.

Palavras chave: semiótica; interação; processos comunicacionais; Greimas' Landowski.

Abstract: From Greimas to E. Landowski. The Experience of Meaning, the Meaning of Experience: Semiotics, Interaction and Socio-comunicational Processes - The aim of this article is to identify and reconstruct the links between Greimas' semiotic approach and that of Landowski. The parallel is developed focusing on the four following trajectories: theoretical, methodological, epistemological and political. The first of those deals with Greimas' theory of narrativity and the expanded form Landowski gave it through his model of the regimes of interactions and meaning. The second tackles the challenges of the semiotic method in front of the complexity of the contemporary world and communication. The third revolves around the dynamics of construction and transformation of meaning. The last one addresses the political implications 
of the semiotic approach. These are elliptical trajectories, through which emerges a non-linear path whose purposes are fundamentally critical.

Keywords: semiotics; interaction; communicational processes; Greimas; Landowski.

\section{Sentir/Dissentir}

Contágio, corpo, estesia, união, presença, paixões sem nome. Os conceitos com os quais me deparei a primeira vez que ouvi falar Eric Landowski dissolviam aos poucos a confiança teórica que acreditava ter conquistado até então. Era o outono de 2002, e eu era um estudante do segundo ano do Curso de Graduação em Ciências da Comunicação da Universidade La Sapienza de Roma, fascinado por Saussure e Greimas, os quais havia descoberto no primeiro módulo da cadeira de semiótica discursiva, ministrado pela professora Isabella Pezzini. Como e porque a teoria do professor visitante estava relacionada à teoria de Greimas - a maneira como a dobrava, a estendia, a complementava -, confesso, eu não entendia.

O sentido não apenas se compreende inteligivelmente, como também se apreende sensivelmente, no e pelo corpo, dizia Landowski em seu italiano afrancesado. Era o que ele definia o problema do contágio del senso (o contágio do sentido), que Greimas vislumbrou em Da Imperfeição (GREIMAS, 1987, trad. port. 2002) e que requeria, segundo ele, uma reformulação dos velhos modelos semióticos.

Naquela época não me interessei muito. Parecia-me tudo um pouco naive (ou talvez naive fosse eu). Eu e meus colegas, que acabáramos de ler Forme estetiche e societá di massa, de Alberto Abruzzese (1973) e A Invenção do cotidiano de Michel de Certeau (1998), estávamos mais preocupados no que chamávamos, parafraseando em voz baixa Landowski do fundo da sala de aula, o problema do contágio del dissenso (o contágio do dissenso), isto é, nas maneiras de desmascarar as estruturas de poder enraizadas em nossa universidade e em nosso universo social mais próximo (a Roma do começo do novo milênio), bem como na elaboração e na disseminação de táticas para driblá-las, algo para que os "velhos modelos" de Greimas me pareciam mais férteis e úteis.

Não imaginava, naqueles dias, que quinze anos mais tarde me encontraria sentado em uma mesa ao sul do equador, prestes a começar um artigo sobre os elos entre Greimas e Landowski. Ademais no centenário do nascimento do semioticista lituano. De lá para cá, dúvidas se dissiparam, outras permaneceram, novas surgiram. A semiótica enfrenta novos desafios. Os processos socioculturais e comunicacionais e os fenômenos midiáticos contemporâneos forçam mais uma vez a teoria a rever suas posições e empreender novos caminhos. Ciente disso, e em razão disso, é então com uma boa dose da curiosidade, da ingenuidade e da impertinência daqueles tempos que me proponho a escrever estas páginas.

Minha intenção não é filológica, nem sistêmica. Não quero fazer, aqui, uma história geral das ideias semióticas ou sociossemióticas, nem reconstruir e organizar linearmente 
os nexos (e os atritos) entre a trajetória intelectual dos dois autores. Inclusive porque acaba de ser publicado, no Brasil, um livro do próprio Landowski (2017a) em que a trama de tais relações é narrada, em primeira pessoa, por quem as viveu e as elaborou. Meu propósito é, ao contrário, crítico e especulativo. Com foco em alguns temas-chave, o que irei desenhar é um percurso errático de idas e vindas, curvas, síncopes, saltos, um percurso assumidamente oblíquo e parcial, na dúplice acepção do termo, isto é, incompleto e de parte, o qual, longe de querer abarcar, exaurir ou proferir verdades sobre Landowski e Greimas, busca esboçar uma possível releitura de sua obra e colocar novos possíveis problemas, divergindo humildemente, quando proveitoso, do caminho dos dois. Um percurso, para usar um termo caro a Landowski (2014a), elíptico, cuja evolução pretende seguir a forma como ele procurou desdobrar o pensamento de Greimas - tensionando-o sem nunca chegar a rompê-lo -, bem como a forma como o pensamento deste pode ainda desdobrar aquele de Landowski.

Para tanto, identifiquei quatro feixes de elipses através dos quais me parece profícuo desenvolver o confronto entre os dois semioticistas: teórico, metodológico, epistemológico e político. Ao cerne do primeiro coloca-se a questão do ponto de vista semiótico sobre os processos socioculturais e comunicacionais e a problemática greimasiana da narratividade, expandida e redefinida por Landowski (2014a) em seu modelo dos regimes de sentido e interação; a segunda foca nos desafios do método semiótico diante da complexidade do mundo e da comunicação contemporânea; a terceira gira em torno do tema da emergência e da transformação do sentido; a quarta, por fim, concerne às premissas e as consequências políticas da abordagem semiótica.

\section{Elipses teóricas}

\section{Semiótica ou sociossemiótica?}

Há quem ainda acredite que o objeto de investigação da semiótica greimasiana limite-se ao texto strictu sensu, isto é, à obra acabada, literária, pictórica, fotográfica, cinematográfica, etc., isolada de seu "contexto", seja qual for o significado atribuído a este termo. Trata-se de uma visão equivocada, cuja fortuna deve-se a uma leitura restrita "greimasianista", como ironiza Landowski (2017a, p. 159) - do próprio conceito greimasiano de texto ${ }^{1}$ e do tão célebre quanto mal compreendido slogan "Fora do texto não há salvação!".

Nada de mais falso. Para Greimas o texto nunca foi um "objeto físico", uma "coisa" (um livro, um filme, um quadro, uma fotografia). Muito pelo contrário, "texto" sempre foi um "modelo" para a construção e a descrição de qualquer tipo de fenômeno, independentemente de sua natureza expressiva e de seu tamanho. Em outras palavras:

1 Pense-se, a este propósito, na crítica que Paul Ricœur dirigiu a Greimas nos anos oitenta do século passado. Segundo o filósofo, "a ciência do texto" poderia abordar apenas suas "leis internas", sendo incapaz de dar conta do que se situa "à montante" e "à jusante" dele (RICOEUR, 1994, p. 86). 
do ponto de vista semiótico greimasiano nenhum objeto de análise, mesmo aquele com fronteiras mais aparentemente definidas (um romance de Calvino, uma canção de Chico Buarque, um quadro de Botticelli, um filme de Woody Allen) é dado a priori, mas "se constitui apenas de elementos semióticos conformes ao projeto teórico da descrição" (GREIMAS; COURTÉS, 2008, p. 503, destaque nosso). Projeto teórico cujas coordenadas são definidas, no caso de Greimas, por alguns princípios epistemológicos de fundo (a primazia da relação sobre os termos; a narratividade enquanto condição universal da experiência humana; a natureza intimamente discursiva do real e do social) e pelo quadro teórico-metodológico definido pelos níveis do Percurso Gerativo de Sentido (o quadrado semiótico, a gramática narrativa e o esquema narrativo canônico, a enunciação, os processos de tematização e figurativização, etc.).

Ora, é fato que, ao usar expressões como "A semiótica do texto. Exercícios práticos" como subtítulo de uma obra que analisa um conto de Maupassant (GREIMAS, 1993a), Greimas pode ter contribuído a criar, dentro e fora dos recintos acadêmicos, alguma ambiguidade sobre a real acepção que ele conferia ao termo "texto" (MARRONE, 2007, p. 241). Contudo, é igualmente verdade (e seria injusto omitir) que, dos primórdios ao fim de sua trajetória intelectual, Greimas desenvolveu, ao lado de estudos sobre textos literários, pesquisas que concernem problemáticas e objetos de cunho eminentemente "macro-social". Entre eles, destacam-se: a moda (GREIMAS, 2000); a linguagem gestual (GREIMAS, 1975); os mitos, o espaço, a cidade, a história (GREIMAS, 1976). Ou seja: o objeto da semiótica nunca foi, não é, nem nunca será o "texto-objeto-fechado" (livro, foto, quadro, filme, etc., que, aliás, muitas vezes fechado nem é), mas sim o "sentido" e sua articulação sob forma de "significação". Como aponta Landowski na Introdução de A Sociedade Refletida, é preciso reconhecer que "a seu modo e desde a origem, foi exatamente do 'real' considerado como uma linguagem e até mesmo do 'vivido' encarado como efeito de sentido que a semiótica se ocupou constantemente" (LANDOWSKI, 1992, p. 207).

É com base nesses pressupostos que a sociossemiótica surge, nos anos 1970, como um desdobramento da semiótica que se propõe a "edificar com urgência uma conceptualização semiótica do 'social'" (LANDOWSKI, 2017a, p. 175). Como afirma Landowski, sob esta perspectiva, "o 'real' que ela [a sociossemiótica] se atribui como objeto, identificado às condições socialmente construídas da significância de nossos discursos e de nossos atos, não é (...) mais que outra forma do textual" (LANDOWSKI, 1992, p. 207).

Para isso, conta Landowski, tornou-se necessário lutar contra "a interpretação greimasianista do maldito slogan 'Fora do texto não há salvação!"' (LANDOWSKI, 2017a, p. 170), apontando como e porque fazer semiótica "não consiste em fazer abstração do contexto, mas, ao contrário, em incluir, no texto - mais exatamente, no objeto semiótico em construção - tudo (e nada mais do que) aquilo que faz parte do campo de pertinência necessário à sua constituição enquanto objeto de sentido" (LANDOWSKI, 2017a, p. 171).

A opinião pública, o discurso jurídico, os regimes de visibilidade, as condições semióticas da interação (LANDOWSKI, 1992), as tipologias da personalidade política, 
o espaço, as formas de alteridade, os estilos de vida (LANDOWSKI, 2002): todas as pesquisas desenvolvidas por Landowski nessa primeira fase de seu trabalho mostram bem como a semiótica é capaz de transbordar com desenvoltura os confins do texto-objeto e produzir interpretações originais de fenômenos de amplo alcance sociocultural ${ }^{2}$. Enãoapenas isso: elas revelam como os fenômenos sociais são objetos cujo sentido o semioticista - do mesmo modo que qualquer outro sujeito (LANDOWSKI, 2014a) - é chamado a construir, relacionando, conforme à sua pergunta, às suas hipóteses e ao seu projeto teórico de descrição, as pertinências que ele apresenta e sugere relacionar. Algo que, é o caso lembrar, vale também para os textos-objeto. Com uma diferença, todavia. Enquanto os textos-objeto possuem um plano da expressão previamente estabilizado (como no caso de um quadro, de uma foto ou de uma pintura), os processos de manifestação dos macro-fenômenos sociais são mais efêmeros e voláteis (LORUSSO, 2010) .

Ou talvez seria o caso começar a dizer re-construir. Sim, porque, como se lê nas entrelinhas das citações acima mencionadas, antes de ser construído pelo olhar e pelas escolhas do semioticista, o social - ou o real, tanto faz - é construído, retomando as palavras de Landowski, pelos discursos que nele circulam e pelos atos dos sujeitos que nele interagem, ou, conforme uma outra conhecida definição do autor, pelas formas através das quais "a comunidade social se oferece em espetáculo a si mesma e, ao fazer isso, dota-se das regras necessárias a seu próprio jogo" (LANDOWSKI, 1992, p. 14).

Landowski reelabora aqui dois dos pilares teórico-epistemológicos fundamentais da semiótica de Greimas.

O primeiro, esboçado pelo autor em Semântica Estrutural (1966, tr. port. 1973) e demarcado com maior clareza no ensaio Condições por uma semiótica do mundo natural (1968, tr. port. 1975, p. 46-85), é definido pela ideia de que o mundo "real", mesmo o mundo "natural" das qualidades sensíveis, ganha forma, diante de nós, apenas através da ação de um conjunto de linguagens, discursos e práticas histórica, cultural e socialmente sedimentadas, os quais constituem a grelha ou o filtro para a sua apreensão. Em outras palavras: não há diferença entre o mundo real ou natural e o "mundo do senso comum" (GREIMAS, 1973, p. 15). Nascemos e vivemos em um mundo já significante, no qual "o problema do sentido não se coloca, o sentido é colocado, se impõe como uma evidência" (GREIMAS, 1975, p. 13) e é por isso que, enquanto sujeitos deste mundo, somos, como costumava dizer Greimas retomando a versada máxima de Merleau-Ponty (1999, p. 18), "condenados ao sentido" (cf. GREIMAS 1975).

2 A forma como a teoria greimasiana das modalidades é usada por Landowski para construir um modelo geral da sintaxe social do ver é, no que tange a essa questão, exemplar (LANDOWSKI, 1992, p. 85-101).

3 Lanço então uma provocação: porque não pensarmos na possibilidade de reservar o termo "texto" apenas ao "texto-objeto-supostamente-fechado" e, como sugere e tem feito Landowski, começarmos a chamar nossos "objetos sociossemióticos" (a cidade, as práticas de vida, o modelo de cultura e a identidade de uma nação) apenas "objetos", deixando claro que o que importa não é o fato deles poderem ou não ser definidos enquanto "textos", mas o ponto de vista (semiótico) através do qual os se analisa? 
O segundo é que a significação, entendida por Greimas enquanto atividade de tradução e, portanto, de produção do sentido (GREIMAS; COURTÉS, 2008, p. 460), deve ser considerada como um fazer que "reúne numa única instância o enunciatário-intérprete (já que a significação não é uma produção ex-nihilo) e o enunciador-produtor" (GREIMAS; COURTÉS, 2008, p. 460). Ou seja, para dizê-lo nos atuais termos de Landowski (2014a), o sentido surge sempre da interação ${ }^{4}$.

Retomarei o assunto mais adiante, já que seus desdobramentos se referem mais diretamente às elipses epistemológicas do que àquelas teóricas. Adianto apenas que Landowski opta, na esteira de tais reflexões, por reescrever a fórmula merleaupontiana. Na ótica da interação, afirmar que somos "condenados ao sentido" torna-se, segundo o autor, inadequado. Mais correto é dizer que somos condenados "a construir o sentido" (LANDOWSKI, 2014a p. 14). Isso porque o sentido emerge apenas graças a alguém que, de alguma forma, o traz à tona. No entanto, é possível fazer um passo além. Juntando as duas perspectivas - a do sentido enquanto camada de significações sedimentadas na qual somos catapultados no momento em que viemos ao mundo e a do sentido enquanto resultado da interação - pode-se dizer que nossa sina é outra. Não somos condenados nem ao sentido, nem a construir o sentido, mas sim a re-construir o sentido. Reconstrução que, como procurarei demonstrar, pode seguir, por um lado, os programas ou a intencionalidade de um dado destinador/enunciador, ou, pelo outro, os caminhos mais imprevisíveis de outros regimes de interação, que podem levar a reconfigurar (por ajustamentos sucessivos) ou subverter (por acidentes ou séries de acidentes pontuais) as configurações precedentes.

Dito isso, parece-me suficiente e proveitoso tirar dessas considerações preliminares uma primeira conclusão de caráter geral, que pode talvez parecer banal, mas da qual nunca deveríamos nos esquecer e que não nos deveríamos cansar de repetir aos alunos de graduação e pós-graduação que se aproximam de Greimas: antes de ser um método - ou pior, uma caixa de ferramentas passíveis de serem aplicadas a objetos de naturezas diversas - a semiótica e a sociossemiótica são uma maneira de olhar e abordar o mundo e seus fenômenos. Um olhar profundamente anti-essencialista, pelo qual nada - mundo, fenômenos, objetos, sujeitos, o social, a cultura, etc. - tem uma forma e uma identidade fixa, aprioristicamente definida e a-discursiva, nem nada existe independentemente de alguém que com ele interage, re-construindo e apreendendo, assim, seu sentido, seja este alguém semioticista ou não. Afinal, tanto para Greimas quanto para Landowski, o sentido é também isso: a própria experiência - intersubjetiva - do sentido.

\section{A narratividade além: sentido, interação, risco}

A interação. Eis o conceito que caracteriza a segunda elipse através da qual Landowski estende a teoria de Greimas. Seguindo as diretrizes esboçadas pelo mestre, Landowski

4 Assim delineada, essa definição do conceito de significação remete claramente à problemática da enunciação (GREIMAS; COURTÉS, p. 166-169). Sobrepondo as propostas de Greimas e Landowski, Ana Claudia de Oliveira desenvolveu recentemente um modelo que busca dar conta das tipologias de interações discursivas que o ato da enunciação estabelece entre enunciador e enunciatário (OLIVEIRA, 2013). 
têm insistido, desde a Sociedade Refletida, na necessidade de atrelar a problemática do sentido àquela da interação, pensando tanto o social, quanto o discurso como "espaços de interação" (LANDOWSKI, 1992, p. 12) e atribuindo o caráter político de ambos à sua capacidade de realizar "certos tipos de atos sociais transformadores das relações intersubjetivas" (LANDOWSKI, 1992, p. 10).

Entretanto, é em As interações arriscadas (2005, tr. port. 2014a) e nas publicações imediatamente sucessivas - que retomam as postulações intermediárias dos ensaios que compõem Presenças do outro (1997, tr. port. 2002) e Passions sans nom (2004) e de textos como Aquém ou além das estratégias, a presença contagiosa (2005) - que a tese landowskiana ganha contornos definidos, assumindo a forma de um verdadeiro modelo teórico que se propõe a dar conta tanto dos regimes de sentido e interação que caracterizavam a gramática narrativa standard de Greimas, quanto de outros regimes que o semioticista lituano tinha vislumbrado sem, contudo, elaborá-los de modo sólido, coerente e coeso.

Landowski defende que, ao dar forma ao nível narrativo do Percurso Gerativo de Sentido, Greimas identificou - explícita ou implicitamente - apenas dois precisos regimes de interação e sentido.

O primeiro é o regime da programação, fundado na regularidade e na previsibilidade, que Greimas vislumbra - embora sem abordá-lo enquanto tal - em ensaios clássicos como, por exemplo, A sopa ao pistou (GREIMAS, 1996). Os sujeitos que interagem sob a égide desse regime limitam-se a seguir à risca percursos e programas narrativos preestabelecidos por algum enunciador-destinador (por um chefe de cozinha, pela igreja, pelo governo nacional, pela secretária do trânsito) ou historicamente, socialmente e culturalmente sedimentados, dos quais, muitas vezes, esquece-se a origem (as etiquetas gastronômicas, as formas de cumprimentar, etc.). O que pode conduzir, como advertia Greimas em Da imperfeição, à usura do sentido ou a uma rotina insignificante.

O segundo é aquele da manipulação, ao qual Greimas dedicou, ao longo de seu trabalho, maior atenção. Fase inicial do esquema narrativo canônico, o regime da manipulação baseia-se em uma intencionalidade de tipo estratégico, entendida como traço distintivo de um destinador que busca levar um destinatário a querer ou a dever fazer alguma coisa e agir conforme seus planos. Para que isso aconteça, o destinatário deverá, portanto, aceitar o contrato proposto pelo destinador e engajar-se, enquanto sujeito, em um determinado programa narrativo, adquirindo, em seguida, competências de tipo modal (poder-fazer, saber-fazer).

Ambos os regimes respondem àquela que Landowski define a lógica da junção, que prevê que as relações intersubjetivas sejam mediadas por objetos de valor específicos, com os quais deve-se ou se quer entrar em conjunção ou disjunção (a sopa, no caso da receita). E não apenas isso: tanto a programação quanto a manipulação inscrevemse em uma constelação de caráter existencial que Landowski (2014a, p. 80) define como a "constelação da prudência", ou seja, em um universo onde o risco de que surjam 
(dos processos interacionais) sentidos imprevistos, novos e inusitados é circunscrito e pode ser relativamente controlado (risco mínimo no caso da programação e limitado no caso da manipulação).

No entanto, continua Landowski, saindo dos confins da gramática narrativa clássica e retomando as proposições sobre a estesia e os acidentes estéticos da cotidianidade formuladas por Greimas em Da Imperfeição (1987, tr. port. 2002), torna-se possível postular a existência de outros dois regimes que respondem a uma lógica profundamente diferente daquela que rege os dois primeiros, que Landowski chama de lógica da união. Nesses casos, a interação e o sentido não dependem da mediação e da transferência de objetos de valor (cf. LANDOWSKI, 2004, p. 110), mas emergem e se constroem por meio do contato direto, do contágio, do corpo a corpo e da co-presença sensível - "i-mediata" (LANDOWSKI, 2017a, p. 156) - entre um sujeito e um "outro", seja este outro um sujeito humano em carne e osso, um objeto, um espaço, etc. Motivo que leva Landowski a inserir tais regimes em uma outra constelação existencial, chamada, não por acaso, constelação da "aventura". Mas vejamos em detalhe de que regimes se trata.

O primeiro é o regime do acidente, fundado no princípio do alea e, logo, em um nível máximo de risco. É o regime da insensatez, no qual o acaso irrompe em sua forma mais pura, como no caso de terremotos e outros desastres naturais, deixando-nos atordoados e atônitos. Contudo, é possível que alguns sujeitos decidam assentir ao risco, elegendo-o como norte de suas vidas e interações cotidianas, como no caso de quem pratica esportes extremos nas metrópoles contemporâneas (DEMURU; MENDES; PEREIRA, 2014). Ou ainda, que busquem atribuir um sentido ao acidente assentindo a alguma instância superior que o teria supostamente causado (deus, o diabo, os astros). Uma escolha que, como pode-se inferir, começa a deslocar seu percurso rumo ao regime da manipulação ${ }^{5}$.

O segundo é o regime do ajustamento, o qual merece uma análise mais aprofundada. Parece-me, pois, que Landowski formule, sem distingui-las teoricamente, duas tipologias diversas de ajustamento.

Por um lado, temos um ajustamento (que, por enquanto, em ausência de uma definição melhor, chamarei de ajustamento 1) entendido como "interação entre iguais" (LANDOWSKI, 2014a, p. 50). Neste caso, os sujeitos interagentes constroem, a partir de suas competências estésicas, isto é, sentindo-se reciprocamente, uma relação que pode levar a uma "realização mútua" (LANDOWSKI, 2014a, p 54). A dança - ou melhor, um certo modo de dançar - é o exemplo que resume de maneira mais nítida essa relação igualitária. Pode-se dançar, diz Landowski, seguindo passos preestabelecidos (programação). Pode-se dançar, ainda, buscando impor ao parceiro um estilo (manipulação). Ou pode-se dançar, ao contrário, ajustando-se sensivelmente ao companheiro ou a companheira, buscando realizar-se não independentemente do outro, mas apenas "por meio da realização mesma

5 Por esta razão, ao lado da denominação de "regime do acidente", Landowski adota, ao mesmo tempo, aquela de "regime do assentimento" (LANDOWSKI, 2008b; 2014). 
do outro dançarino" (LANDOWSKI, 2014a, p. 54-55). Uma interação, como argumenta Landowski, guiada pela "busca de relações de reciprocidade ajustadas às potencialidades do outro" (LANDOWSKI, 2017b, p. 5, trad. minha).

Por outro lado, emerge, em Landowski, uma outra maneira de entender o ajustamento. Diversamente da primeira, esta segunda perspectiva concebe o ajustamento como a resposta de um sujeito às tentativas de programação e manipulação de sua existência. Neste caso, não estamos mais diante de uma interação entre iguais, mas sim entre sujeitos situados em diferentes posições de poder. Tem-se, aqui, a resistência, por meio de ajustamentos progressivos, de um sujeito a um outro sujeito que pretende e tende a dominá-lo (de novo: um outro sujeito em carne e osso, uma cidade, uma situação, mas também um governo ou um período de crise política e democrática como aquele que vivemos, hoje, no Brasil). Trata-se de um estilo de conduta - e de vida - que Landowski compara à arte da guerra de Sun Tzu, à inércia do general russo Kutuzov perante o exército napoleônico e à guerrilha afegana que desestabilizou a armada estadunidense, ou seja, a uma prática militar, que consiste "em deixar, na medida do possível, que o outro [siga] sua própria propensão a fim de tirar partido disso, ajustando-se, precisamente, a seus movimentos" (LANDOWSKI, 2014a, p. 56). Muitos dos exemplos concretos citados como casos de ajustamento por Landowski em sua obra inserem-se exatamente nesta diretriz: o haïkido, a métis grega, o jeitinho brasileiro (DEMURU, 2015) - práticas e posturas existenciais que encarnam esta capacidade de otimizar os recursos dos quais se dispõe, driblando as barreiras e os desejos de controle e domínio do outro ${ }^{6}$.

Assim delineados, os quatro regimes compõem um quadrado semiótico no qual, no eixo dos contrários, a programação se opõe ao acidente e, no eixo dos subcontrários, a manipulação se opõe ao ajustamento. Porém, diferentemente do que acontecia no quadrado de Greimas, as passagens entre um polo e o outro não se realizam por saltos entre quatro posições pontuais, mas, gradualmente, ao longo de uma elipse. Ou seja: há a possibilidade de uma série potencialmente infinita de posicionamentos intermediários e sobreposições entre um regime e o outro. Divergências à parte, o que vale ressaltar é que essas articulações fornecem, em seu conjunto, um quadro geral de uma possível semiótica da experiência (LANDOWSKI, 2017a), bem como um modelo capaz de problematizar a dinâmica dos processos socioculturais e comunicacionais.

Retomarei em breve tais assuntos, explicitando suas implicações semiopolíticas. Seguirei, agora, apontando dois desdobramentos possíveis do modelo landowskiano, os quais, a meu ver, a obra de Greimas pode ainda contribuir a desenvolver.

6 Preciso que, segundo esta leitura, o ajustamento 2 não coincide com o ajustamento fundado na sensibilidade reativa, postulada por Landowski (2014a, p. 52) para problematizar respostas de natureza estésica a acões e programas predefinidos, como no caso de um motorista que se ajusta aos pedais de seu veículo. Assim como o ajustamento 1, ele se inscreve, nos termos que estou aqui propondo, no âmbito da sensibilidade perceptiva, isto é, de um tipo de sensibilidade que "nos permite não apenas experimentar pelos sentidos as variações perceptíveis do mundo exterior (...), mas também interpretar o conjunto dessas soluções de continuidade em termos de sensações diferenciadas que fazem por si mesmas sentido" (LANDOWSKI, 2014a, p. 52). 


\section{A plástica da experiência}

O primeiro desdobramento diz respeito ao "alcance existencial" (LANDOWSKI, 2014a, p. 14) dos regimes de interação e sentido, cuja plausibilidade começamos a entrever nas descrições acima fornecidas. Como escreve Landowski, sob uma perspectiva filosófico-semiótica, o modelo descrito propõe-se também a dar conta "do valor existencial de diferentes 'estilos de vida' possíveis enquanto regimes distintos de relações com o sentido" (LANDOWSKI, 2014a, p. 17).

Vivemos como interagimos, interagimos como vivemos. Programando minuciosamente nossa rotina, manipulando ou nos deixando manipular, assentindo ao acaso ou a um destinador transcendente, ou, ainda, ajustando-nos "ao que der e vier".

Embora prefira a expressão "estilos de vida" ${ }^{\prime}$, Landowski acata aqui algumas das sugestões colocadas por Greimas em Da Imperfeição (2002) e - sobretudo - no ensaio O Belo Gesto (GREIMAS, 1993b), obra na qual o autor reelabora, sob uma perspectiva semiótica, a noção wittgensteiniana de forma de vida, definindo-a como uma configuração ético-prática que se configura, ao mesmo tempo, "como uma filosofia de vida, uma atitude do sujeito e um comportamento esquematizável" (GREIMAS, 1993b, p. 73, trad. minha), orientada por um determinado valor semântico (o absurdo, no caso de Alfred Jarry citado por Greimas em seu estudo, ou o ajustamento, pensando na ótica landowskiana), ou uma série coesa de valores semânticos (o absurdo, a ironia, a alegria, ou a "derrapagem controlada" que mistura ajustamento e acidente, conforme sugere o próprio Landowski [2014a, p. 87]) que o sujeito instaura como norte de sua "organização existencial" (MARRONE, 2007, p. 149, trad. minha).

Entretanto, não é o aspecto semântico - o plano do conteúdo das formas (ou dos estilos) de vida - que me interessa aqui discutir, mas sim seu plano da expressão. Trata-se de uma reflexão que Landowski esboça em seu ensaio Regimes de espaço (2015), no qual procura atribuir a cada regime de interação e sentido uma precisa configuração topológica (o tecido para a programação, a rede para a manipulação, o abismo para o assentimento, a voluta para o ajustamento), e que aguarda (e merece) ulteriores aprofundamentos. Uma vez postulado que a programação, a manipulação, o acidente e o ajustamento podem configurar "valores existenciais" (LANDOWSKI, 2014a, p. 17) que orientam a experiência e o comportamento dos sujeitos, é preciso reconhecer, semioticamente, que tais valores devem necessariamente estar atrelados, no plano da expressão, a traços distintivos que os manifestam e fazem com que os possamos apreender enquanto tais.

Pense-se, a este propósito, nas diferenças superficiais que existem nas narrativas sobre as duas formas de ajustamento (ambas de tipo 2, conforme o a distinção antes elaborada) que se sedimentaram, ao longo do século $\mathrm{XX}$, enquanto epitomes de dois respetivos carateres nacionais: o jeitinho brasileiro e a arte di arrangiarsi italiana (a arte

7 Veja-se, a este propósito, Landowski (2012). 
de se virar). Como procurei demonstrar em estudos anteriores (DEMURU, 2014; 2015), tanto a primeira quanto a segunda apresentam o mesmo núcleo-duro semântico e narrativo de fundo, sendo comumente descritas como filosofias de vida e modelos de conduta que privilegiam o saber-sentir o outro, ajustando-se às suas jogadas e driblando, assim, seus programas e suas tentativas de manipulação. Entretanto, uma análise mais nítida mostra como esses dois estilos constituem, no que diz respeito à sua manifestação no plano da expressão, formas de ajustamentos quase opostas: enquanto a arte de arrangiarsi italiana é um ajustamento linear, anguloso, reto, horizontal, o jeitinho brasileiro é, ao contrário, um ajustamento elíptico, curvo, às vezes circular, aberto.

Dito de outro modo, há uma dimensão plástica dos regimes de sentido e interação, isto é, uma plástica da experiência e dos estilos de vida que precisa ser semioticamente problematizada. É isso mesmo que Greimas evidencia quando afirma que a forma de vida está intimamente vinculada a uma dimensão espetacular, a uma mise en scène que deveria convidar a refletir sobre sua concretude expressiva (GREIMAS, 1993).

Para tanto, os estudos sobre as categorias plásticas começados pelo semioticista lituano, bem como seus desdobramentos elaborados por Jean-Marie Floch (1995) e Ana Claudia de Oliveira $(2004 ; 2017)$, podem fornecer indícios interessantes. A tarefa é árdua e o percurso oblíquo. Porém, é um caminho proveitoso a ser trilhado. Um caminho que, inclusive, permite entrever uma das maiores contribuições que a semiótica pode oferecer ao campo das ciências sociais e da comunicação: a identificação e a análise das modalidades de homologação entre expressões e conteúdos em âmbito macrossocial.

\section{Dinâmicas do sentido}

É claro: as diferenças superficiais entre duas ou mais formas de ajustamento, acidente, manipulação, programação e outros regimes existenciais, podem produzir, voltando ao plano do conteúdo, nuances no que tange seus arranjos de valores. Nesse sentido, o ajustamento italiano é um ajustamento mais prático, cínico e calculado que o brasileiro, o qual, ao contrário, pode ser considerado um ajustamento lúdico e estético, que comporta mais riscos que o outro. O que, pensando no fluxo elíptico do quadrado proposto, leva-me a formular a hipótese de que a arte di arrangiarsi transita entre o ajustamento e a programação, enquanto o jeitinho brasileiro oscila entre ajustamento e acidente.

Chegamos aqui ao segundo desdobramento possível da teoria de Landowski, para o qual Greimas pode ainda contribuir: o modelo dos regimes de interação e sentido pode constituir uma base para teorizarmos, em termos gerais, a dinâmica dos processos socioculturais e comunicacionais, isto é, as formas como as sociedades, as culturas e os processos comunicacionais assumem, em uma determinada área geográfica e em uma determinada época histórica, configurações (aparentemente e momentaneamente) estáveis e as formas como tais configurações evanescem e evoluem. 
Procurarei me explicar a partir de um breve exemplo concreto, extraído da recente história do Brasil. No início de junho de 2013, no penúltimo ano do primeiro mandato de Dilma Roussef, o Movimento Passe Livre (MPL) desce às ruas, em São Paulo e Rio de Janeiro e outras capitais, contra o aumento da tarifa de ônibus (de reais 3,00 a reais $3,20)$. As palavras de ordem e as hashtag que circulam nas redes sociais para convocar as manifestações são claras e focadas: três reais é roubo, por uma vida sem catraca, etc. Em um primeiro momento, as demonstrações contam com um número pouco significativo de participantes, reprimidos, inclusive, pela ação policial. No entanto, pouco depois, após o recrudescimento dos confrontos, cada vez mais pessoas se juntam aos atos. Com o aumento da participação, o rumo semântico dos protestos começa a mudar. São dias de grande incerteza, nos quais os slogans claros e precisos dos primeiros protestos cedem lugar a lemas vagos e indefinidos: \#NãoÉpelosVinteCentavos, \#Changebrazil, \#VerásQueUmFilhoTeuNãoFogeÀLuta, \#AcordaBrasil (Demuru, 2018).

Aproveitando-se desta ambiguidade, a velha mídia, que até então havia condenado as manifestações, inverte perspectiva, elogiando, agora, seu alcance global. Começa a ser promovida a imagem de um Brasil à deriva, no qual nada funciona: "Milhares vão às ruas contra tudo", escreve a Folha de São Paulo no dia seguinte às manifestações do dia 17 de junho, enquanto a bandeira nacional e as camisas da seleção brasileira começam a aparecer nas avenidas, nos perfis de twitter e facebook e em importantes edifícios das cidades brasileiras, como o prédio da Federação das Indústrias do Estado de São Paulo (FIESP), na Avenida Paulista de São Paulo.

Ora, transpondo o modelo dos regimes de Landowski do plano das interações micro para o plano das interações macrossociais, parece-me possível e plausível considerar junho de 2013 enquanto um acidente que faz com que o modelo de Brasil que se sedimentou ao longo da era Lula exploda, dando vida a um momento histórico marcado pelo não sentido, ou melhor, por demasiados sentidos possíveis, como apontam os slogans vagos acima citados (se não é pelos vintes centavos, para que seria então? Como o Brasil deveria mudar?). Não seria essa, afinal, a outra faceta do acidente? A capacidade, ou seja, não de produzir o insensato, mas de trazer à tona sentido demais?

Visto nesses termos, o acidente lembra o conceito de explosão de Jurij Lotman, entendido como um "evento que interrompe a cadeia das causas e dos efeitos e que projeta, na superfície, uma série de eventos igualmente prováveis dos quais é impossível, em princípio, dizer qual se realizará" (LOTMAN, 1995, p. 35, trad. minha). Um evento ao qual segue uma explosão de sentidos - metáforas, paráfrases, rimas, analogias, diferenças de qualquer tipo, não apenas linguísticas - que podem dar lugar a combinações de valores imprevisíveis, impossíveis ou proibidas em uma fase precedente.

À essa explosão, a esse sentido demasiado, as coletividades procuram comumente dar um rumo. Não se trata, contudo, de uma escolha simples e pacífica. Longe de serem pacatos e lineares, os processos comunicacionais que levam a estabelecer um sentido - 
uma direção - aos sentidos imersos durante e após o acidente costumam ser polémicos e tumultuados $^{8}$. O caso brasileiro é, a este propósito, emblemático, pois mostra como, após a ruptura causada por junho de 2013, a mídia procurou manipular e direcionar os sentidos vagos dos protestos rumo à presidência, deslocando-os do nível local das prefeituras e dos estados para o nível global do governo federal, identificando Dilma Rousseff e seu partido como únicos responsáveis pela crise do país e seus principais antisujeitos ${ }^{9}$.

E não apenas isso. O que vale ainda ressaltar é que essa manipulação se fundou, ao mesmo tempo, em uma estratégia sensível de reformulação, enquadramento e redirecionamento da carga estésica surgida nas ruas, isto é, em um processo que Landowski define "manipulação por contágio" (LANDOWSKI, 2008a), típico da comunicação políticomidiática contemporânea e das novas formas de populismo ao redor do mundo (DEMURU; SEDDA, 2018). Hinos cantados à capela nos estádios ao vivo em rede nacional enquanto as câmeras mostram cartazes "contra a corrupção"; momentos de comoção coletiva diante da bandeira brasileira; panelaços nas cidades e vídeos de panelaços nos telejornais e na internet. Tudo isso contribuiu a dar forma ao sentir coletivo e à nova identidade de um suposto "povo brasileiro", construído e retratado como um sujeito "naturalmente dado" e "unido" pelo discurso midiático.

Do acidente à manipulação e da manipulação a um regime complexo que combina, conforme o princípio da recursividade oblíqua proposto por Landowski (2014a, p. 89), manipulação e ajustamento, intencionalidade e sensibilidade, o qual parece desembocar, por sua vez, em uma programação coletiva do agir e do sentir político nacional. Um movimento que, no entanto, não evolui de maneira pontual, mas, para utilizarmos um conceito vislumbrado por Greimas em Da Imperfeição e, ainda, pouco explorado, de modo "turbulento" (GREIMAS, 2002, p. 87). Como defende Paolo Fabbri (2010), ao lado do acidente estético da cotidianidade, Greimas identifica, em sua última obra individual, uma outra modalidade através da qual "o ritmo esgotado" da experiência pode ser revalorizado: a "turbulência", um movimento sustenido e sincopado que, segundo Greimas, pode ressignificar a espera do inesperado, evitando assim que, para o sujeito em busca de sentidos novos, "a iteração das esperas [não] degenere em monotonia" (GREIMAS, 2002, p. 86). Conceito que, transposto na esfera dos processos macrossociais que estou aqui discutindo, pode ser útil para explicar os ritmos através dos quais as elipses entre um regime e outro ganham corpo e sentido.

A este propósito, Landowski tem recentemente proposto um outro conceito que parece apontar caminhos interessantes para abordarmos as evoluções rítmicas dos processos de propagação do "sentido sentido": o alastramento. Trata-se, nos termos do semioticista, de uma forma de interação entre corpos sensíveis e condutores que não corresponde

8 É nesse sentido, como diz Sedda, que a vida das culturas pode ser considerada uma questão "semiopolítica". Entorno ao sentido, pois, "agita-se, pois, uma luta constante" (SEDDA, 2012, p. 16, trad. minha).

9 Não é por acaso que, três anos após as protestas de 2013, em março de 2016, a fachada do mesmo prédio da FIESP foi preenchida, desta vez, com faixas verde-amarelas, cores da bandeira nacional, entrecortadas por uma faixa preta que trazia slogans como "Impeachment" e "Renúncia Já", dirigidos à então presidente Dilma Rousseff, reeleita em 2014 com o 51,64\% dos votos. 
"nem a uma empatia de ordem cognitiva, nem a um contágio viral, mas à expansão por contiguidade dos elementos tocados, à maneira de um incêndio em uma floresta" (LANDOWSKI, 2018, p. 15) $)^{10}$.

O problema está colocado, mas longe de ser resolvido. No entanto, deve-se ressaltar o potencial da revisão do modelo de Landowski nos termos acima propostos. Em diálogo com outras abordagens, como aquela lotmaniana, ela pode contribuir a repensarmos, sob a ótica de um novo estruturalismo dinâmico enraizado na experiência do mundo, a forma e os ritmos por meio dos quais se sedimentam, evolvem, implodem e explodem os sistemas sociais, culturais, políticos e os processos sócio-comunicacionais que os fundam. E isso sem ter necessariamente que escolher entre uma teoria do sensível e uma teoria do inteligível, entre uma teoria do afeto (entendido enquanto único traço distintivo de nossa época) e outra da cognição, mas contemplando, ao contrário, as elipses entre as duas lógicas da junção e da união (SODRÉ, 2006; LANDOWSKI, 2016; 2018).

\section{Elipses epistemológicas}

\section{Entre o sentido}

Desde Semântica Estrutural, Greimas frisou a necessidade de estabelecer um conjunto mínimo e representativo de pressupostos epistemológicos - "tão pouco numerosos e tão gerais quanto possível" (GREIMAS, 1973, p. 15) - que definissem o horizonte e os limites da abordagem semiótica, bem como os critérios de validação de seu método.

Para tanto, Greimas parte, em sua obra seminal, de quatro hipóteses gerais:

i. a significação é onipresente e multiforme e não pode ser eludida (cf. GREIMAS, 1973, p. 15);

ii. a apreensão da significação situa-se no nível da percepção (cf. GREIMAS, 1973, p. 15);

iii. não há solução de continuidade entre o mundo sensível e o mundo do senso comum. (cf. Greimas, 1973, p. 15), ou melhor, como dirá Greimas mais tarde, entre o mundo "natural" e o mundo "sociocultural" (cf. GREIMAS, 1975, p. 46-85);

iv. antes de tudo, "nós percebemos diferenças e, graças a esta percepção, o mundo 'toma forma' diante de nós, e para nós" (GREIMAS, 1973, p. 28).

Na esteira destas primeiras considerações, Greimas busca em sua obra sucessiva, Sobre o Sentido (GREIMAS, 1975), uma solução ainda mais radical ao problema da definição do minimum epistemológico semiótico. A significação é aqui descrita como uma atividade de "transcodificação" fundada em um preciso horizonte de possibilidade: o sentido. Como escreve Greimas: "a significação é, portanto, apenas esta transposição

10 Sobre a problemática do alastramento, veja-se, também, Landowski, $2014 \mathrm{~b}$. 
de um nível de linguagem a outro, de uma linguagem a uma linguagem diferente, e o sentido é apenas esta possibilidade de transcodificação" (GREIMAS, 1975, pp. 13-14).

Pode-se concluir, portanto, como já tinha antecipado no item sobre o ponto de vista semiótico e sociossemiótico, que Greimas pensa o sentido como uma reserva de significações histórica, social e culturalmente sedimentadas, que configura a matéria prima e o ponto de partida de suas futuras transformações. Como ele afirma, "a produção do sentido só tem sentido se for transformação do sentido dado" (GREIMAS, 1975, p. 15), razão pela qual, continua Greimas, "o sentido, enquanto forma do sentido, pode ser definido então como a possibilidade de transformação do sentido" (GREIMAS, 1975, p. 15, destaque do autor $)^{11}$.

Encontra-se aqui resumido o núcleo-duro da epistemologia do projeto científico greimasiano, isto é, a ideia de que o sentido pode ser abordado apenas em uma perspectiva generativa, e não genética. Dele é possível dizer como se manifesta e como se modifica, mas não como nasce ou de onde surge. O verbete "Sentido" do Dicionário de Semiótica é, a este respeito, emblemático: antes de sua manifestação sob forma de significação articulada, "nada pode ser dito do sentido, a não ser que se façam intervir pressupostos metafísicos carregados de consequências" (GREIMAS; COURTÉS, 2008, p. 457).

Como observa Marsciani (2012) a semiótica gerativa greimasiana representa, nesse sentido, um dos êxitos mais radicais da fenomenologia da primeira metade do século XX (Husserl e Merleau-Ponty), a qual se deparou, no final de sua trajetória, com o problema da constituição intersubjetiva do sentido (e não apenas de sua emersão a partir de uma intencionalidade subjetiva), bem como com a questão da necessidade de uma nova cientificidade capaz de descrevê-la. Nas Meditações Cartesianas, Husserl identifica, pois, como último passo da redução egológica, um sistema de intersubjetividade transcendental que precede toda objetividade mundana e funda toda subjetividade, inspirado no conceito leibnizeniano de "comunidade de mônadas" (HUSSERL, 2001).

No entanto, a partir de Semiótica das Paixões, as coisas começam a mudar. O problema passa a ser, agora, aquele da busca das "precondições previas ao surgimento das condições propriamente ditas" (GREIMAS; FONTANILLE, 1993, p. 16), traçadas anteriormente por Greimas. Em poucas palavras, trata-se de buscar uma resposta à pergunta não resolvida sobre a gênese do sentido. O que exige, segundo os autores, a assunção de um discurso epistemológico próximo àquele "das ciências da natureza, quando elas falam, por exemplo, do universo e de suas origens" (GREIMAS; FONTANILLE, 1993, p. 16), bem com a identificação de um novo "mínimo epistemológico", no caso, "O imperativo fenomenológico" (GREIMAS; FONTANILLE, 1993, p. 17). É graças a este imperativo que, conforme as palavras dos autores, a semiótica poderá dar vida "a um espaço teórico 'imaginário' e até mítico, um pouco à maneira desses anjos newtonianos, condutores da atração universal”.

11 É nesse sentido, por ser, ou seja, uma teoria das transformações do sentido que se dão através de encadeamentos sucessivos de efeitos de sentido, que a semiótica greimasiana é, como sugere Marsciani (2017, p. 7), uma verdadeira "teoria da experiência". 
Para construir e articular, com base no imperativo fenomenológico, essa nova epistemologia, Greimas e Fontanille postulam o sentir como precondição mínima do sentido e, ao mesmo tempo, como traço distintivo do "horizonte ôntico" da semiose. E não apenas isso. Por sua vez, o horizonte ôntico é pensado como uma nebulosa percorrida por uma espécie de atração tímica universal - a tensividade-fórica - que remete, enquanto noção teórica, "a uma visão física do mundo [e] a um conceito vitalista-organicista das ciências biológicas" (PEZZINI, 1996, p. XXXVIII).

A mesma linha de raciocínio é levada adiante por Fontanille em suas obras sucessivas, desde Semiótica do Discurso (2015a) até Corps et Sens (2011), passando por Soma et Sema (2004). Fontanille (2004, p. 26) postula o corpo como "mola" e "substrato da semiose", identificando uma evolução linear entre a percepção subjetiva das formas "físico-biológicas" do mundo e a significação (FONTANILLE, 1998, p. 29). Não temos mais, portanto, como havia postulado Greimas, um trânsito de mão dupla entre o mundo do senso comum e a percepção e entre a intersubjetividade e a subjetividade, mas um movimento de sentido único: da percepção dos sentidos físicos-biológicos ao mundo do senso comum e da subjetividade à intersubjetividade.

Não é esta a sede adequada para uma reconstrução detalhada de tais processos (DEMURU, 2011). Limito-me a destacar uma incongruência relativa à impossibilidade, percebida pelos próprios Greimas e Fontanille na segunda parte de Semiótica das Paixões, de conciliar um discurso epistemológico próprio das ciências da natureza com uma teoria semiótico-discursiva da experiência humana e sociocultural do sentido. Ao analisarem um discurso passional concreto, aquele da avareza, os autores percebem, pois, que "a dificuldade principal, no tratamento dos universos passionais deve-se ao retorno obstinado da instância cultural, que intervêm em todos os lugares e em todos os níveis" (GREIMAS; FONTANILLE, 1993, p. 158). O que os leva, consequentemente, a admitir que "o horizonte do ser que se vislumbra por detrás da tensividade fórica estaria em parte culturalmente e economicamente determinado" (GREIMAS; FONTANILLE, 1993, p. 158). Conclusão à qual Fontanille chega também em Pratiques Sémiotiques, quando reconhece, na esteira de Lévinas, que a análise das práticas mostra como, na verdade, é a "intersubjetividade que fornece a condição originária da subjetividade" (FONTANILLE, 2008, p. 198, trad. minha) e que isso deveria valer "também para a carne" (FONTANILLE, 2008, p. 198, trad. minha). Uma perspectiva que o semioticista abraça e desenvolve em seu último livro sobre as formas de vida (FONTANILLE, 2015b), onde o ser-juntos assume um papel central. No entanto, aqui como em Corps et sens (2011), quando o assunto é o corpo, o corpo próprio do sujeito individual parece revestir ainda um papel de primeiro plano, precedendo a relação intercorporal que, logicamente, o deveria fundar.

Diferentemente de Fontanille, Landowski não pensa o corpo enquanto operador primigênio da semiose. Apesar de insistir, como vimos, nos processos de emergência do sentido a partir do contágio e da co-presença sensível dos sujeitos engajados na interação, 
o sentir e o sensível não constituem, no modelo landowskiano, o lugar único e a sede originária da semiose, mas sim uma, entre outras, de suas possíveis formas de articulação.

À luz de quanto visto anteriormente a respeito das dinâmicas de sentido previstas pela estrutura elíptica do quadrado dos regimes de interação, parece-me então possível formular uma leitura epistemológica da teoria de Landowski ancorada na seguinte hipótese: o modelo landowskiano segue e, em certo sentido, leva às extremas consequências a epistemologia de Greimas. Como para o semioticista franco-lituano, não se trata, para Landowski, de estabelecer um lugar e um momento de gênese do sentido, mas de refletir sobre o fluxo de sua transformação a partir de diversas tipologias de interação. Isso por uma razão muito simples: porque o sentido não surgiu, nem surge, como diz Greimas, ex nihilo ou de um lugar só, seja o corpo, a mente ou sabe-se lá o que. O sentido apenas está, sempre esteve, circula e sempre circulou entre nós, como nós, "de manhã à noite, e da idade pré-natal a morte" (GREIMAS, 1973, p. 15), sempre circulámos e circularemos nele, sendo condenados, intersubjetivamente, a re-construí-lo.

Ora, como vimos, o modelo de Landowski sugere que essa re-construção pode se configurar, como uma mera repetição, no caso de quem segue à risca esquemas, rotinas e pistas de sentido prefixadas (programação); como uma leitura, no caso de quem adere à intencionalidade estratégica de um dado destinador (manipulação); como uma recriação, no caso de quem reinventa, à moda de um bricoleur, as configurações preexistentes (ajustamento); como uma subversão, no caso de quem as rompe e as revira de cabo a rabo (acidente) ${ }^{12}$. De todo modo, o que vale ressaltar é que qualquer re-construção do sentido em forma de significação articulada se dá, como postulava Greimas, a partir do diálogo sensível e inteligível entre, ao menos, dois sujeitos (individuais ou coletivos). São eles que, juntos, definem aquela instância produtora de sentido que Oliveira, em seus estudos sobre as interações discursivas, chama, frisando o fato de que o sentido é sempre uma construção plural, "sujeito complexo da enunciação" (OLIVEIRA, 2013).

A intersubjetividade define, portanto, o pilar epistemológico tanto da semiótica greimasiana quanto da sociossemiótica landowskiana. A partir das indicações dos dois autores, parece-me possível atribuir-lhe, agora, um dúplice estatuto semiótico. Em primeiro lugar, a intersubjetividade é o que possibilita a existência do sentido, seja do sentido entendido enquanto reserva de significações sedimentada através de interações e enunciações precedentes, seja do sentido que resultará de novas interações e enunciações. Em segundo lugar, a intersubjetividade é o que funda a subjetividade, do mesmo modo que, especularmente, a relação intersubjetiva (plural) entre corpos é o que funda o corpo (singular).

Estamos diante de uma perspectiva próxima às tendências epistemológicas da filosofia contemporânea, às propostas, por exemplo, de Jean Luc Nancy (2001) sobre o "ser singular plural" e a originalidade do "com". Este último, em particular, defende que

12 Essa classificação, de caráter provisório, é inspirada na tipologia de viralização dos memes da internet apresentada por Fechine (2017) no Colóquio Internacional Greimas, realizado na Pontifícia Universidade Católica de São Paulo em março de 2017. A autora individua quatro formas de propagabilidade: a replicação, a imitação, a recriação e a invenção. Ver também Fechine (2018). 
"antes de qualquer intencionalidade fenomenológica e antes da constituição egológica, como também antes da consistência coisal [ou corporal, poderíamos acrescentar] enquanto tal, há a co-originariedade do com" (NANCY, 2001, p. 57, trad. minha). Há mais: o "Com" do qual fala Nancy remete tanto à dimensão interacional da experiência da qual fala Landowski - "o com é a situação originária: poderíamos até dizer que é o que define a situação em geral", diz o filósofo (NANCY, 2001, p. 57, trad. minha) - quanto ao conceito de sentido entendido enquanto "possibilidade de transformação do sentido", do qual, antes de sua manifestação, "nada pode ser dito, a não ser que se façam intervir pressupostos metafísicos carregados de consequências", ou, quem sabe, os anjos newtonianos. Como o sentido greimasiano, o "com" de Nancy é, pois, "a estrutura geral de cada con-sistência e de cada con-sciência e que não podemos alcançar, pois ela é estreitamente contemporânea a toda existência e a todo pensamento" (NANCY, 2001, p. 57, trad. minha).

Relações e ecos interdisciplinares à parte, eis uma primeira consequência: a elipse através da qual Landowski des-dobra a epistemologia de Greimas preserva e estende as diretrizes epistemológicas traçadas pelo fundador da semiótica francesa. Longe de renegar a matriz estrutural da semiótica greimasiana em nome de uma mera e pura fenomenologia do sujeito individual, o modelo landowskiano a renova e a dinamiza, fundando (e fundando-se em) uma epistemologia sócio-semio-fenomenológica segundo a qual, na esteira do principio saussuriano que atribui à relação a primazia sobre os termos, a intersubjetividade precede a subjetividade e o sentido não tem uma gênese, mas circula e se evolui sem parar.

\section{Do imediato ao i-mediato}

No entanto, se assumirmos até o fundo esta perspectiva, torna-se necessário problematizar em outros termos a questão do "imediato". Partindo do pressuposto de que nascemos e vivemos imersos em um mundo significante, até que ponto podemos falar em "contatos imediatos", em presenças que fazem sentido "imediatamente"? Não seriam também os nossos corpos e os nossos sentires, para usar uma expressão antiga, "efeitos de sentido"? Memórias de outros corpos e outras interações? De onde vem, ou seja, nossa competência estésica? E como muda?

Landowski (2009) procura dar uma resposta a esta pergunta através da problematização da questão da aquisição - via aprendizagem prática - da nossa capacidade de sentir o outro. No entanto, talvez seja mais proveitoso enquadrar o assunto a partir de uma outra perspectiva. Ora, posto que o sentido greimasianamente e landowskianamente entendido é uma reserva histórica, cultural e socialmente sedimentada de significações que possibilita suas evoluções e, ao mesmo tempo, o resultado do jogo das interações entre sujeitos diversos, não seria talvez coerente explicitar que o sentido "imediatamente" apreendido pelo sentir é também passível de assumir formas diversas conforme às épocas 
históricas e as esferas socioculturais de pertencimento? Os discursos das (e sobre as) duas modalidades de ajustamento encarnadas pelo jeitinho brasileiro e pela arte di arrangiarsi italiana discutidas anteriormente indicam exatamente isso: que o "sentido imediatamente sentido" pode se concretizar, ainda que preservando um núcleo comum de valores profundos, por meio de arranjos plásticos-figurativos completamente diferentes. Nesta ótica, o problema da "imediatez do sensível" passa a ser, portanto, um problema de tipologias e estilos sociais e culturais. Talvez Landowski não quisesse dizer isso, mas o fato dele utilizar, em sua última obra, Com Greimas, o termo "i-mediato" ou o adverbio "i-mediatamente" separado pelo hífen (LANDOWSKI, 2017a, p. 156-194) parece-me um convite - consciente ou inconsciente, pouco importa - a problematizar a questão nesses termos. Um convite que, no futuro próximo dos estudos sociossemióticos, não deverá nem poderá ser recusado.

\section{Elipses metodológicas}

\section{Em busca de relações}

Revelou-se uma aporia. Como já esclareceu Marrone (2007, p. 246), o sentido enquanto objeto de conhecimento da semiótica possui, ao mesmo tempo, duas características aparentemente opostas: por um lado, ele é "dado" - o que, bem entendido, não significa que o sentido seja fixo e imutável, mas apenas que ele possui, antes de o abordarmos, uma configuração semiótica momentânea que constitui o ponto de partida de suas análises semióticas; pelo outro, ele é "construído", ou seja, recortado e tornado pertinente a partir de um preciso ponto de vista teórico, epistemológico e metodológico (MARRONE, 2007, p. 246). Razão pela qual a empiria não tem, sob o perfil semiótico, nada de natural ou imediato, mas é sempre, segundo a terminologia que resolvi aqui adotar, re-construída (conforme, diria Greimas, um preciso projeto de descrição).

Contudo, continua Marrone (2007, p. 46), o problema é que a relação entre os quatro níveis nos quais se funda e se articula a semiótica greimasiana - empírico, teórico, metodológico, epistemológico -, costuma ser pensada como uma evolução linear, que vai do empírico ao epistemológico. O que leva à consolidação de distorções e mal-entendidos sobre o modus operandi e os pressupostos da disciplina, entre os quais destaca-se a ideia de que a semiótica seja apenas uma teoria e um método que se "aplicam" cegamente a quaisquer objetos empíricos.

Nada de mais falso: como vimos, a teoria e a epistemologia semiótica são radicalmente construtivistas e a evolução e as passagens entre os níveis não são lineares, mas elípticas e reticulares, assim como no Dicionário de Semiótica redigido por Greimas e Courtés (1979, trad. port. 2008), onde cada verbete remete a outro: "o nível empírico não é o primeiro nível da semiótica, mas é postulado como tal apenas a partir de uma operação preventiva de construção [teórica, epistemológica e metodológica] do dado" (MARRONE, 2007, 
p. 247, trad. minha). De novo: o objeto da semiótica não é uma "coisa" ou um conjunto de "coisas", mas as "relações" (inteligíveis, sensíveis, inteligíveis e sensíveis, de qualquer tipo) através dos quais o sentido é produzido e assume - momentaneamente - uma forma. O que implica postular "uma instância de qualquer tipo - cultural, histórica, social, científica - isto é, um sujeito construtor individual ou coletivo que estabeleça $\mathrm{a}$ [s] relaç[ões], que a[s] torne[m] pertinente[s], que a[s] faça valer no universo sociocultural" (MARRONE, 2007, p. 247, trad. minha). Em suma: a teoria e a epistemologia semiótica são uma teoria e uma epistemologia das relações.

O mesmo vale para o método. O que o método semiótico busca é identificar e estabelecer relações entre os traços distintivos (do plano da expressão e do plano do conteúdo) que os objetos apresentam, independentemente de seu tamanho. Isso posto, é preciso reconhecer, todavia, que quando se passa da análise dos "textos-objetos" àquela dos "objetos sociossemióticos" - um estilo de vida nacional, as práticas de vida de uma cidade, uma dança ou, ainda, o papel que um "texto-objeto" (uma obra literária, musical, etc.) desenvolve ou desenvolveu em uma determinada comunidade sociocultural - identificar e estabelecer tais relações torna-se uma tarefa mais complexa. De onde começar e como proceder para construir, destrinchar e interpretar os nossos objetos? Como apreender e recortar um objeto que, diferentemente de um romance, um filme, um quadro, não tem um plano da expressão previamente estabilizado (LORUSSO, 2010)? O que, em suma, sob o perfil do método, define a especificidade do ponto de vista semiótico sobre o social?

Dada a relação elíptica que une os quatro níveis da semiótica, é claro que os modelos teóricos são também modelos metodológicos. No seu conjunto, o Percurso Gerativo de Sentido (dos processos de actorialização, espacialização, temporalização à relação entre temas e figuras, da gramática narrativa ao quadrado semiótico), o conceito de isotopia, as categorias plásticas e os processos de homologação simbólicas e semissimbólicas entre o plano da expressão e o plano do conteúdo constituem, inclusive para os objetos sociossemióticos (ou melhor, para a análise sociossemiótica de um qualquer objeto de sentido), um sólido ponto de partida.

Complementado o Percurso Gerativo, o modelo dos regimes de sentido e interação de Landowski fornece uma lente metodológica para abordar a construção do sentido "em ato", bem como para analisar, como vimos, os arranjos de valores existenciais que subjazem aos estilos de vida ou, ainda, as trajetórias através das quais o sentido evolui. Assim, o modelo apresenta-se como a sintaxe geral que articula as relações entre as sintaxes particulares dos distintos regimes sócio-comunicacionais através dos quais o mundo é perenemente ressignificado.

\section{Olhares oblíquos}

No entanto, não é esse o aspecto que quero aqui contemplar. Ao contrário, quero apontar dois caminhos preliminares a qualquer análise conduzida a partir dos modelos 
citados, os quais, ao meu ver, definem a especificidade do ponto de vista semiótico sobre o social e a cultura. Trata-se de dois trajetos convergentes que correspondem, respectivamente, a duas operações complementares de recortes de relações, as quais tanto Greimas quanto Landowski (em particular no que se refere à segunda), nos convidam discretamente a realizar. A primeira operação diz respeito à necessidade de relacionar micro e macro configurações de sentido - isto é, à necessidade de buscar as isotopias (plásticas, figurativas, temáticas, narrativas) que textos-objetos ou práticas de vida com confins mais ou menos delimitados entretêm com os discursos, as axiologias e as ideologias do universo ou dos universos socioculturais em que se inscrevem e transitam. A segunda refere-se à exigência de atrelar as interações em ato às suas traduções discursivas, ou seja, a observar conjuntamente a "experiência" e o "discurso da experiência" (LANDOWSKI, 2007 , p. 42), seja este discurso produzido pelos sujeitos envolvidos na experiência ou por enunciadores externos.

Não me refiro, aqui, apenas aos momentos em que Greimas defende, em seus ensaios declaradamente sociossemióticos, a necessidade de elaborar uma "gramática sociossemiótica" que dê conta das "dimensões e [d] as articulações significativas das macro-sociedades atuais" (GREIMAS, 1976, p. 58), ou ainda, aos momentos em que Landowski afirma explicitamente que, sob o perfil teórico, apesar de constituírem regimes diversos de apreensão do sentido, a experiência e a narração sobrepõem-se reciprocamente sem pausa (LANDOWSKI, 2007, p. 28). Refiro-me, ainda, e mais, a uma abordagem metodológica muitas vezes implícita, que emerge em filigrana de suas análises de objetos e casos concretos.

Quando Greimas analisa a linguagem gestual não está preocupado em revelar simplesmente sua gramática interna, mas em refletir sobre as maneiras através das quais as linguagens não-verbais contribuem, do mesmo modo que a verbal, a recortar e dar forma ao nosso mundo natural, isto é, à maneira como apreendemos suas qualidades sensíveis (GREIMAS, 1975, p. 46-85); quando ele analisa o belo gesto, o que o inquieta não é o funcionamento isolado do ato (a sua lógica espetacular, a sua configuração estética), mas a maneira como o ato e o discurso de um sujeito (individual ou coletivo) propõemse a substituir uma nova moral à moral sedimentada em uma dada esfera sociocultural (GREIMAS, 1993); quando se debruça sobre o acidente estético nas obras de Calvino, Cortázar, Tanizaki, etc. não está meramente problematizando o tema da estesia no discurso literário, mas procurando identificar uma semiótica da recriação e da reinvenção da cotidianidade a partir do corpo e do sensível (GREIMAS, 2002).

Paralelamente, quando Landowski analisa o discurso da carta não está interessado em desvelar seus procedimentos enunciativos clássicos (as marcas da enunciação enunciada, os processos de debreagem e embreagem do texto verbal) mas a forma como a carta toda pode tornar o outro presente e instaurar um novo regime de interação, fundado em uma 
lógica (a da presença) ao mesmo tempo oposta e complementar à primeira (LANDOWSKI, 2002, p. 165-181); quando estuda a morte de Lady Diana enquanto evento midiático, o que pretende revelar não são as articulações internas dos textos e dos discursos jornalísticos, televisivos, etc., mas as modalidades através das quais a pessoa, a imagem da pessoa (seu olhar), o funeral, as narrações do e sobre o funeral contribuíram, juntos, a instaurar um tipo de interação coletiva que deu forma - corpo e alma - a um povo e a uma nação (LANDOWSKI, 2001); quando aborda os retratos das personalidades políticas presentes nos jornais, o que quer debater não é apenas o sentido das imagens ou da linguagem fotográfica no âmbito midiático, mas o processo de definição de um conjunto de estratégias que definem, novamente, em relação com outros discursos (como aquele publicitário), a sua presença no campo da política e da sociedade (LANDOWSKI, 2004); quando afirma que o acidente desemboca, frequentemente, em algum tipo de manipulação, o que está implicitamente nos dizendo é que o sentido do evento depende sempre, de algum modo (como no caso de Diana ou de um terremoto lido como um gesto de vingança divina), dos discursos que dele e sobre ele serão construídos (LANDOWSKI, 2014a).

Tal conjunto de operações me parece definir um sólido ponto de partida para abordar o social e a cultura a partir de um ponto de vista semiótico. Em outros termos, trata-se de construir corpus heterogêneos relacionando micro e macro configurações de sentido (um funeral, um programa televisivo, o discurso mediático sobre o funeral, o discurso da nação) e contemplando as imbricações entre experiência e narração. Ou, ainda, de reconstruir modelos e formas de cultura e sociabilidade a partir da constituição de "séries" de elementos diversos e de diversos "tamanhos", cujas relações podem parecer invisíveis quando os observamos pela primeira vez. Praticar, em suma, como diz Sedda, "um olhar estrábico" (...) um jogo constante e circular de definições internas e externas [...] que estabelecem similaridades e diferenças, de olhares analíticos cada vez mais detalhados e imaginações culturais cada vez mais vastas" (SEDDA, 2012, p. 12, trad. minha).

\section{Elipses políticas}

\section{Olhares comprometidos}

Sob essa perspectiva, a construção semiótica de um corpus de análise é também um ato político. Explico porque a partir de um outro exemplo concreto, inspirado no trabalho de pesquisa que desenvolvi, entre 2012 e 2015, no Centro de Pesquisas Sociossemióticas de São Paulo ${ }^{13}$.

Suponhamos que eu escreva um pré-projeto que vise abordar, de um ponto de vista sociosemiótico, os novos estádios de futebol de São Paulo (a Arena Corinthians, no bairro de Itaquera, e o Allianz Parque, em Perdizes) e seu impacto na vida da cidade.

13 Trabalho realizado no âmbito do Projeto Temático “Práticas de vida e produção de sentido da metrópole de São Paulo: regimes de visibilidade, regimes de interação e regimes de reescritura", coordenado por Ana Claudia de Oliveira (2017). Tanto a pesquisa individual quanto aquela coletiva receberam apoio da Fundação de Amparo à pesquisa do Estado de São Paulo (FAPESP). 
Para dar corpo e continuidade à pesquisa, a melhor opção seria ir até meu objeto e começar por observar como os estádios se apresentam e o que acontece dentro deles e ao seu redor. Sobrepondo a lente da sociossemiótica de Landowski e da etnosemiótica de Marsciani (2007), perceberei logo, se tiver sorte, algumas saliências plásticas e figurativas potencialmente significantes. Notarei, talvez, que, em relação aos antigos estádios da cidade, como o Pacaembu, as novas arenas apresentam algumas diferenças: (i) os degraus das arquibancadas de concreto foram substituídos com assentos com encostos - o que pode impedir a realização das coreografias clássicas das torcidas; (ii) nos ambientes internos, tal como nos shopping center de São Paulo, o mármore é um dos materiais mais utilizados; (iii) as lojas, os bares e os pontos de venda em geral multiplicaram-se; (iv) a comida, cada vez mais sofisticada, não é mais a de antes; (v) as comunidades situadas nos arredores dos estádios foram confinadas dentro de muros de concreto e tapumes construídos especificamente para escondê-las (no caso da Arena Corinthians); (vi) enfim, as pessoas caminham, encontram-se, param para conversar apenas nas calçadas opostas àquelas localizadas logo abaixo das paredes externas dos estádios, protegidas, por sua vez, por altas grades de ferro (no caso do Allianz Parque).

Chegou agora o momento de colocar alguma pergunta ao meu objeto empírico e começar a entender o que quero do meu estudo. A este propósito, apresentam-se algumas possibilidades. Posso perguntar, por exemplo, qual é a função que os novos estádios cumprem dentro do contexto urbano, pressupondo, talvez, que tais edificações estão deixando de ser lugares destinados ao esporte para se tornarem verdadeiros centros comerciais (e terei muito provavelmente elementos para confirmar tal hipótese). Ainda, posso perguntar qual é a dinâmica interna às práticas que têm lugar fora e dentro dos estádios, individuando suas variações durante os diversos momentos do dia e da semana e os modos em que os sujeitos atualizam ou não atualizam os traços plásticos do ambiente. Ou, ao contrário, posso apostar um pouco mais alto e perguntar se, por acaso, há alguma correspondência entre tais práticas, o arranjo plástico dos novos estádios, o mármore, as lojas, as comunidades escondidas, os muros, etc. e a dinâmica mais geral de controle, elitização e higienização que caracteriza, em maior escala, as cidades brasileiras. Perguntar se e como os novos estádios contribuem a alimentá-la, estabelecendo "séries" ${ }^{14}$ de relações com outros objetos, valores, axiologias, regimes de sentido e interação do universo social do qual os primeiros fazem parte. Perguntar, ainda, se existem - e, se existem, como se configuram - formas de resistência ou práticas alternativas à tais regimes.

São operações como estas que definem, ao meu ver, a politicidade da abordagem semiótica. Operações que favorecem um deslocamento do olhar - um olhar, para usarmos uma expressão cara a Landowski (2001), sempre e profundamente "comprometido"- e nos instigam, como dizia antes, a buscar relações entre micro e macro configurações de

14 O problema da construção de séries de objetos diferentes na análise arqueológica das culturas foi debatido por Michel Foucault em Arqueologia do Saber (1969). Para uma revisão semiótica do conceito vejam-se Sedda (2012) e Lorusso (2010). 
sentido, que ajudem a desvelar as relações de força que se escondem atrás da superfície de nossa existência e das quais, muitas vezes, não percebemos a presença (cf. Sedda, 2012). De desmascarar os dispositivos de programação que tendem a usurar e dessemantizar nossas vidas cotidianas, as estratégias de manipulação de quem pretende impor seu próprio querer, as formas de assentimento a uma instância transcendente (Deus, o acaso, a internet, os astros, um líder populista, etc.) à qual recorremos para dar sentido às fatalidades de nosso destino. De mostrar, enfim, os percursos de lutas através dos quais os sujeitos procuram desconstruí-los, ressemantizá-los e ultrapassá-los (LANDOWSKI, 2017a; 2017b).

\section{Por uma semiótica r-existencial}

É nesse sentido que, como dizia Greimas, a semiótica "poderia ser, em um última instância, uma terapêutica do social", isto é, "uma espécie de ciência prima, que procure morder o social e não se limite a permitir sua compreensão" (GREIMAS 1995, p. 169, trad. minha).

Em textos mais recentes Landowski tem insistido muito nesse aspecto, chegando, inclusive, a se posicionar a favor do regime do ajustamento, entendido enquanto uma nova "ecologia do sentido" que, por sua vez, poderia fundamentar uma nova "ecologia do social" (LANDOWSKI, 2017b, p. 4; LANDOWSKI, 2017a). Isso num gesto de oposição contra os regimes de interação tecnocráticos e burocráticos que buscam programar e tornar insignificantes nossas vidas reduzindo as nossas possibilidades de escolha; contra os regimes fatalistas nos quais os sujeitos remetem suas decisões a alguma instância superior, assentindo a suas visões de mundo; contra os usos "manipulatórios", no sentido comum da palavra, de certas estratégias de persuasão em vigor nos regimes democráticos (Landowski, 2018). Em contrapartida, a sociossemiótica frisa a possibilidade de um regime interacional no qual os atos e os comportamentos não mais resultariam de decisões unilaterais tomadas "diante de um mundo objeto colocado à distância, mas surgiriam de uma série de ajustamentos sensíveis entre a dinâmica das situações vividas e aqueles que as vivem" (LANDOWSKI, 2017b, p. 3, trad. minha). Vislumbra-se, assim, na semiótica e no fazer semiótica, a possibilidade e a necessidade de "pleitear (sem excesso de ilusão) em favor de uma gramática radicalmente outra, criativa de sentido, e de valor em seu princípio mesmo: a do ajustamento ao outro - sob todas as suas formas" (LANDOWSKI, 2017a, p. 207).

Impossível não perceber nessas palavras os ecos da exortação com a qual Greimas fecha Da imperfeição, convidando-nos a buscar "mais luz" através "da vigilante espera de uma estesia única, de um deslumbramento ante o qual não nos encontraríamos obrigados a fechar as pálpebras" (GREIMAS, 2002, p. 91). Trata-se de um projeto - de uma tensão rumo a uma organização social diferente - que o próprio Landowski chega a reconhecer um tanto "utópica" (LANDOWSKI, 2017b, p. 3) e, porém, diante da qual, enquanto semioticista comprometidos, somo chamados a tomar posição.

Antes de mais nada, é preciso abordar com os devidos cuidados as diversas formas de ajustamento que se apresentam diante de nossos olhos de semioticista, bem como 
as suas imbricações com os outros regimes de sentido e interação. A este propósito, o que não podemos nos permitir é confundir, em nossas análises, casos de ajustamentos 1 com casos de ajustamentos 2, ignorando ou subestimando as relações de força em jogo na interação e atribuindo o estatuto de "interação sensível entre pares" a interações que, ao menos inicialmente, apresentam-se claramente enquanto "interações ímpares", nas quais um sujeito em posição desvantajosa faz uso de sua astúcia sensível para resistir às tentativas de programação e manipulação de um outro sujeito, qualquer ele seja.

Ora, no mundo em que vivemos, neste mundo sublunar da história humana em que, para dizê-lo com Ginzburg (2012, p. 32), "os indivíduos, de modo irreversível, nascem, infligem sofrimentos ou são a eles submetidos", os ajustamentos de tipo 2 são ainda predominantes. Pergunto-me então provocativamente: até que ponto as práticas concretas dos sujeitos encarnados que abordamos em nossas análises são e podem ser definidas ajustamentos entre pares? Não seria a maioria de nossos ajustamentos cotidianos apenas um conjunto de ajustamento de tipo 2? Não quero assumir aqui o papel do apocalíptico. Não acho, pois, que não existam ou que não sejam possíveis ajustamentos de tipo 1. Estou apenas alertando sobre a necessidade de não trocar os pés pelas mãos, bem como sobre a urgência, tão relevante quanto esta, de chamar as coisas pelo seu nome.

À luz de tais considerações, poderia se dizer que o ajustamento de tipo 1 é um ajustamento utópico, enquanto o ajustamento de tipo 2 é um ajustamento político. Não que isso signifique que o primeiro não seja ou não possa ser considerado como tal. Pelo contrário, enquanto tensão utópica rumo a um outro regime de sociabilidade possível, ele é um projeto de caráter eminentemente político. No entanto, operar essa distinção e reservar este termo para o segundo parece-me hoje, um ato necessário.

Além disso, distinguir entre essas duas formas de ajustamento nos convida a colocar novas questões que podem nos levar a desdobrar nossos métodos e nossas teorias. Em quais esferas socioculturais acontecem ou podem acontecer os ajustamentos utópicos de tipo 1? Apenas na esfera das micro-interações intersubjetivas, cara a cara, corpo a corpo, de nossa cotidianidade, ou também em esferas macrossociais? O que acontece quando a mídia entra em jogo? Quanto duram ou podem durar os ajustamentos entre pares antes de serem cooptados por outros regimes (o que coloca, inclusive, um problema teórico sobre a cifra rítmica e aspectual dos regimes de sentido e interação)? Não seriam, esses encontros, apenas outros pequenos acidentes, outras efemeridades que dilaceram nosso cotidiano deixando, em nossos corpos, a marca sensível, aprazível e, ao mesmo tempo, dolorosa, de uma interação inesperada? Ainda: é possível que uma série de pequenos ajustamentos políticos provoque um acidente que subverta os sentidos dominantes? Como se dá esta passagem? E como se transita daqui para o ajustamento utópico?

Bem entendido: isso não significa que não possamos, enquanto semioticistas, almejar a construir novas configurações sócio-existenciais utópicas. Era exatamente este o fim terapêutico-social da semiótica ao qual se referia Greimas. Mas, infelizmente, este é um assunto que ultrapassa os limites desta reflexão. 
O que nos resta, por ora, é uma mera constatação: para se tornar uma semiótica política capaz de morder a realidade, uma semiótica existencial há de ser, necessariamente, uma semiótica resistencial. Uma semiótica que desvende os regimes de interação e sentido através dos quais o poder se manifesta e se camufla. Uma semiótica que aborde, chamando-os pelo que são, os ajustamentos políticos que os sujeitos tecem diante das formas de sentido dominantes. Uma semiótica que se coloque, ela mesma, enquanto fazer teórico e analítico, como um ato de resistência. Para que haja, se não mais luz, ao menos mais consciência de nossa condição social e humana.

Paolo Demuru é professor titular do Programa de PósGraduação em Comunicação da Universidade Paulista - UNIP. Pós-doutorado no PPG em Comunicação e Semiótica da Pontifícia Universidade Católica de São Paulo e no PPG em Comunicação da Universidade Federal de Pernambuco. Doutor em Semiótica pela Universidade de Bologna e doutor em Semiótica e Línguística Geral pela Universidade de São Paulo. Autor do livro Essere in gioco. Calcio e cultura tra Brasile e Itália. É membro do Centro de Pesquisas Sociossemióticas - CPS.

paolodemuru@gmail.com

\section{Referências}

ABRUZZESE, A. Forme estetiche e società di massa: arte e pubblico. Veneza: Marsilio, 1973.

DEMURU, P. Brasile: il calcio, la storia, I'identità. Un esercizio di semiótica della cultura. Tese de doutorado. Istituto Italiano di Scienze Umane, Università di Bologna, 2011.

Essere in gioco. Calcio e Cultura tra Brasile e Italia. Bologna: Bup, 2014.

Malandragem vs Arte di arrangiarsi: Stili di vita e forme dell'aggiustamento tra Brasile e Italia. Actes Sémiotiques, Limoges, n. 118, 2015. (http://epublications.unilim.fr/revues/as/)

Os símbolos nacionais nos processos sociais e midiáticos. Uma análise sociossemiótica da bandeira e do hino nacional brasileiro de junho de 2013 aos dias de hoje. XXVII Encontro Anual da Compós, Pontifícia Universidade Católica de Minas Gerais, Belo Horizonte, junho de 2018. Anais... Pontifícia Universidade Católica de Minas Gerais, Belo Horizonte, junho de 2018.

DEMURU, P.; MENDES, E. F.; PEREIRA, T. Praticando São Paulo: interações público-privadas e reescritura da cidade pelo esporte. In: Oliveira, Ana Claudia de. São Paulo público-privado: uma abordagem sociossemiótica. São Paulo: Estação das Letras e Cores, 2014.

DEMURU, P.; SEDDA, F. Da cosa si riconosce il populismo. Ipotesi semiopolitiche. Actes Sémiotiques, Limoges, n. 121, 2018. Disponível https://www.unilim.fr/actes-semiotiques/

FABBRI, P. Turbolenze. Determinazione e impredicibilità. In: MIGLIORE, T. (org). Incidenti ed esplosioni: A.J Greimas, J. M. Lotman per una semiotica della cultura. Vários tradutores. Roma: Aracne Editrice, 2010. 
FECHINE, Y. Interações na cultura participativa. Uma semiotização arriscada. São Paulo, Pontifícia Universidade Católica, 2017 (Comunicação oral).

. Pour une sémiotique de la propagation: invention et imitation sur les réseaux sociaux. Actes Sémiotiques, 121, 2018.

FLOCH, J.-M. Identités visuelles. Paris: PUF, 1995.

FONTANILLE, J. Soma e séma: figures du corps. Paris: Maisonneuve \& Larose, 2004.

Pratiques sémiotiques. Paris: PUF, 2008.

Corps et sens. Paris: PUF, 2011.

Semiótica do discurso. Trad. Jean Cristtus Portela. São Paulo: Contexto, 2015a.

Formes de vie. Liège: Presses Universitaires de Liège, 2015b.

FOUCAULT, M. Archéologie du savoir. Paris: Gallimard, 1969.

GINZBURG, C. História noturna. São Paulo: Companhia das Letras, 2012.

GREIMAS, A. J. Semântica Estrutural: pesquisa de método. Trad. Haquira Osakabe e Izidoro Bilkstein. São Paulo: Cultrix, 1973.

Sobre o sentido. Vários tradutores. Petrópolis: Editora Vozes, 1975.

. Semiótica e ciências sociais. São Paulo: Cultrix, 1976.

. Maupassant: a semiótica do texto - exercícios práticos. Trad. Teresinha Michels e Carmen

Gerlach. Florianópolis: Editora da UFSC, 1993a.

. Le beau geste. Recherches sémitioques, Toronto, XIII, 1-2, 1993 b.

. Greimas in Discussione. Trad. italiana de Gianfranco Marrone. In: Marsciani, Francesco (org). Miti e Figure. Bologna, Esculapio, 1995.

. A sopa ao 'pistou' ou a construção de um objeto de valor". Trad. Edith Lopes Modesto.

Significação. Revista Brasileira de Semiótica, 11-12, p. 7-21, 1996

. La Mode en 1830. Langage et société: écrits de jeunesse. Paris: PUF, 2000.

. Da Imperfeição. Trad. Ana Claudia de Oliveira. São Paulo: Hacker, 2002.

GREIMAS, A. J.; COURTÈS, J. Dicionário de Semiótica. Vários tradutores. $1^{\mathrm{a}}$ ed. São Paulo: Contexto, 2008.

GREIMAS, A. J.; FONTANILLE, J. Semiótica das paixões: dos estados de coisas aos estados de alma. Trad. Maria José Rodrigues Coracini. São Paulo: Editora Ática, 1993.

HUSSERL, E. Meditações cartesianas: introdução à fenomenologia. Trad. Frank Oliveira. São Paulo: Madras, 2001.

JULLIEN, F. Les transformations silencieuses. Paris: Le livre de poche, 2009.

LANDOWSKI, E. A sociedade refletida: ensaios de sociossemiótica. São Paulo: Educ/Pontes, 1992. . O olhar comprometido. Galáxia, São Paulo, n. 2, p. 19-56, 2001.

. Presenças do outro: ensaios de sociossemiótica. São Paulo: Perspectiva, 2002. 
Passions sans nom. Paris: PUF, 2004.

Les interactions risquées. Limoges: Pulim, 2005.

. Unità del senso, pluralità di regimi. In: MARRONE, Gianfranco et. Al. Narrazione ed esperienza: intorno a uma semiotica della vita quotidiana. Roma: Meltemi, 2007. dez, 2008a.

La politique-spectacle revisitée: manipuler par contagion. Versus, Milão, p.13-28, maio-

Assentiment. In: Ablali, Driss; Ducard, Dominique. Vocabulaire des études sémiotiques, Besançon, Presses Universitaires de Franche-Comté, 2008.

. Avoir prise, donner prise. Actes Sémiotiques, Limoges, n. 112, 2009.

. Regime de sens et style de vie. Actes Sémiotiques, Limoges, n. 115, 2012.

. Interações arriscadas. Trad. Luiza Helena Oliveira da Silva. São Paulo: Estação das Letras e Cores e Centro de Pesquisa Sociossemióticas, 2014a.

. Pour A. In: Fechine, K; Castilho, C. Rebouças, M. Albuquerque, M. Semiótica nas práticas sociais. São Paulo: Estação das Letras e Cores, 2014b.

Regimes de espaço. Galáxia, São Paulo, n. 29, p. 10-27, 2015.

2016.

Entre comunicação e semiótica, a interação. Parágrafo, São Paulo, v.4, n. 2, p. 2017-217,

Com Greimas: Interações semióticas. São Paulo: CPS e Estação das Letras e Cores, 2017a.

Petit manifeste sémiotique en I'honneur et à l'attention du camarade sociologue Pekka Sulkunen. Actes Sémiotiques, Limoges, n. 120, 2017b.

. Populisme et esthésie. Actes Sémiotiques, Limoges, n. 121, 2018.

LORUSSO, A. M. Semiotica della cultura. Roma: Laterza, 2010.

LOTMAN, Y, M. Cercare la strada. Modelli della cultura, Venezia: Marsilio, 1994.

MARRONE, G. L'invenzione del Testo. Appunti per una ricerca. Versus. Quaderni di Studi Semiotici, n. 103-105, 2007, p. 237-252.

MARSCIANI, F. Tracciati di etnosemiotica. Milano: FrancoAngeli, 2007. (Tr. fr., Les arcanes du quotidien. Limoges: Pulim, 2017).

Ricerche Semiotiche I. Bologna: Esculapio, 2012.

A partire dagli effetti di senso. Le trasformazioni sotto l'apparire. Actes Sémiotiques, Limoges, n. 120, 2017.

MERLEAU-PONTY, M. Fenomenologia da Percepção. São Paulo: Martins Fontes, 1999.

NANCY, J. L. Essere singolare plurale. Torino: Einaudi, 2001.

OlIVEIRA, A. C. de (Org.). Semiótica Plástica. São Paulo: Hacker Editores, 2004.

As interações discursivas. In: OLIVEIRA, Ana Claudia de. (org.). As interações sensíveis: ensaios de sociossemiótica a partir da obra de Eric Landowski. São Paulo: Estação das Letras e Cores, 2013.

São Paulo e Roma: práticas de vida e sentido. São Paulo: Estação das Letras e Cores, 2017.

PEZZINI, I. Introduzione a Greimas. In: GREIMAS, Algirdas Julien; FONTAINILLE, J. Semiotica delle 
passioni: dagli stati di cose agli stati d'animo. Milano: Bompiani, 1996.

RICCEUR, P. Tempo e narrativa. Tomo I. Trad. Constança Marcondes Cesar. Campinas: Papirus Editora, 1994.

SEDDA, F. Imperfette traduzioni. Roma: Nuova Cultura, 2012.

SODRÉ, M. As estratégias sensíveis: afeto, mídia e política. Rio de Janeiro: Vozes, 2006.

Texto recebido em 11/08/2019

e aprovado em 26/10/2019. 